\title{
BIOPILE TO TREAT OIL-CONTAMINATED SOILS: SOME BRAZILIAN EXPERIENCE
}

\author{
Marcia Marques ${ }^{1,2}$ \\ Jorge Antonio Lopes ${ }^{3}$ \\ Marcelo Alarsa ${ }^{4}$ \\ Marcos F. Ferrari ${ }^{4}$ \\ Graciane Silva $^{1}$ \\ Amanda França ${ }^{1}$ \\ Rio de Janeiro State University-UERJ, Brazil \\ Linnaeus University-LU, Sweden \\ TRANSPETRO, Brazil \\ Lumina Resíduos Industriais (Foz de Iguaçu-Grupo Odebretcht)
}

\begin{abstract}
Remediation of soils contaminated with petroleum and its products became a major issue in all regions of the world where on-shore and off-shore exploitation, refining, transportation and storage of these products are carried out intensively. Many techniques for remediation of contaminated areas have been developed and tested during decades, being bioremediation both in-situ and ex-situ tow of the available options that require further development, which are currently capturing the attention of different sectors involved with the problem in Brazil. This paper presents the historical perspective of the increasing problem that initially appeared in the most traditional industrialized countries and currently has been intensified in countries with growing economy and technological development such as Brazil. Technological options for remediating the areas, variables relevant to the cleaning process, as well as the most recent trends in Brazil regarding the use of different techniques, with focus on biopiles are briefly presented.
\end{abstract}

\section{KEYWORDS}

Bioremediation; biopile; bioaugmentation; cost-effectiveness; contaminated sites; petroleum hydrocarbons.

\section{INTRODUCTION}

With the displacement of productive centres to developing countries and strengthening of several economic sectors, including information, knowledge and technology, remarkable changes in soil uses have occurred since the 1970's, resulting in empty industrial parks and brownfields. More than one million of contaminated or potentially contaminated industrial and commercial areas are estimated inside Europe[1]. In 
Netherland, for instance, there are about 400 thousand sites suspected of being contaminated [2]; inn Germany, this number is around 362 thousands [3]; in Belgium, seven thousands and in France, more than 4 thousand of such sites exist [4]. According to the Swedish Environmental Protection Agency, 45 thousand sites were suspected of being contaminated in Sweden, being half of them with no defined responsibility as required by the Environmental Code [5]. More than 10 thousand of these sites belong to the highest risk category and required investigation. The costs of cleaning up a contaminated site averages 3.5-4.5 million Euros. It was estimated that around 4.9 billion Euros would be required to remediate the most seriously contaminated sites. With an investment of around 108 million Swedish kronor a year (of which, the Swedish State pays half), by 2050, only 1,500 contaminated sites among 45 thousands estimated will be cleaned up. In USA, among 1569 contaminated sites classified in the priority category, one thousand had been rehabilitated in 2009 [6]. Cities such as Pittsburgh (Pennsylvania), Buffalo (Nova York), Lowell (Massachusetts) in USA, as much as Liverpool in England, Kitakyushu in Japan and many others in UK, France, Belgium, Germany, Spain and the whole Eastern Europe are examples of decommissioning of industrial areas, with reduction of 40 to $80 \%$ of the productive industrial parks, which generate and transfer to a large extent to the public sector, the economic, social and environmental problems resulting from this phenomenon [6].

\section{THE MARKET IN BRAZIL (SAO PAULO STATE AS AN EXAMPLE)}

In Brazil, according to a preliminary evaluation carried out in 2003, it was estimated the existence of more than 15 thousand potentially contaminated areas. In this total amount, Sao Paulo is the state that has the most comprehensive database of potentially contaminated areas, with 2.9 thousand contaminated areas confirmed in different stages of investigation and remediation [7]. The main states in the southeast, south and northeas regions are currently organizing step by step their databases about contaminated sites. The expectation is that the scenario in other important states from the economic viewpoint is not far from the one found in Sao Paulo, due to similarities in trade, industry and agriculture activities. In Sao Paulo, during the years, due to intensive population growth and urbanization, the changes occurred, mostly with the use of old industrial areas for commercial and residential uses [1]. Most changes occurred during the last five years, suggesting that this trend of reusing industrial areas for commercial and residential purposes is relatively recent. For most of these areas no previous diagnosis was carried out to assess the status of the soil and groundwater. Among 2070 areas that undergone changes in land use from industrial to other uses between 1996 and 2004, about 533 (25\%) were turned into more sensitive uses with the construction of households, schools, shopping centres [1]Ayres da Silva, 2002). About 12 thousand potentially contaminated areas only in the city of Sao Paulo were produced as a result of leaking, liquid waste infiltration and illegal solid waste disposal. Similar to what happened in France during the 1970's it is likely that at least 6 thousand cases of contamination will be confirmed, so remediation measures of different types can be implemented. In 2009 almost 3 thousand sites had already been conformed in the contaminated category [7] as shown in Table 2. Fuel stations represent $78 \%$ of these contaminated sites, followed by industrial sites $(13 \%)$, commercial sites $(4 \%)$ solid waste final disposal sites (3\%) and accidents or unknown contamination sources $(1 \%)$. The fact that $78 \%$ are fuel stations, are due to the command and control instruments in this sector, which require remediation of sites in order to deliver installation and operation licenses. As soon as other economic activities establish the 
same level of requirement followed by command and control instruments, the percentage of contaminated sites due to other activities than fuel storage will increase. According to the database of CETESB, the main contaminants groups identified during the last two decades are aromatic solvents, liquid fuels, with $65 \%$ of the total contaminants according to Figure 2, illustrating how the contaminated areas are distributed in terms of contaminants in Figure 1.

Table 1. Contaminated areas, November 2009, Sao Paulo State-Brazil [7].

\begin{tabular}{|l|r|r|r|r|r|r|}
\hline & \multicolumn{7}{|c|}{ Activities } \\
\hline Region & Trade & Industry & Residues & $\begin{array}{r}\text { Fuel } \\
\text { Stations }\end{array}$ & $\begin{array}{r}\text { Accidents/ } \\
\text { unknown }\end{array}$ & Total \\
\hline Sao Paulo State & 32 & 83 & 25 & 675 & 3 & 818 \\
\hline Sao Paulo Metr. Region & 23 & 108 & 17 & 375 & 5 & 528 \\
\hline Sao Paulo inland & 53 & 129 & 33 & 900 & 13 & 1128 \\
\hline Sao Paulo littoral & 13 & 34 & 20 & 199 & 2 & 268 \\
\hline Paraíba Valley & 2 & 28 & 1 & 130 & 1 & 162 \\
\hline Total & 123 & 382 & 96 & 2,279 & 24 & 2,904 \\
\hline
\end{tabular}

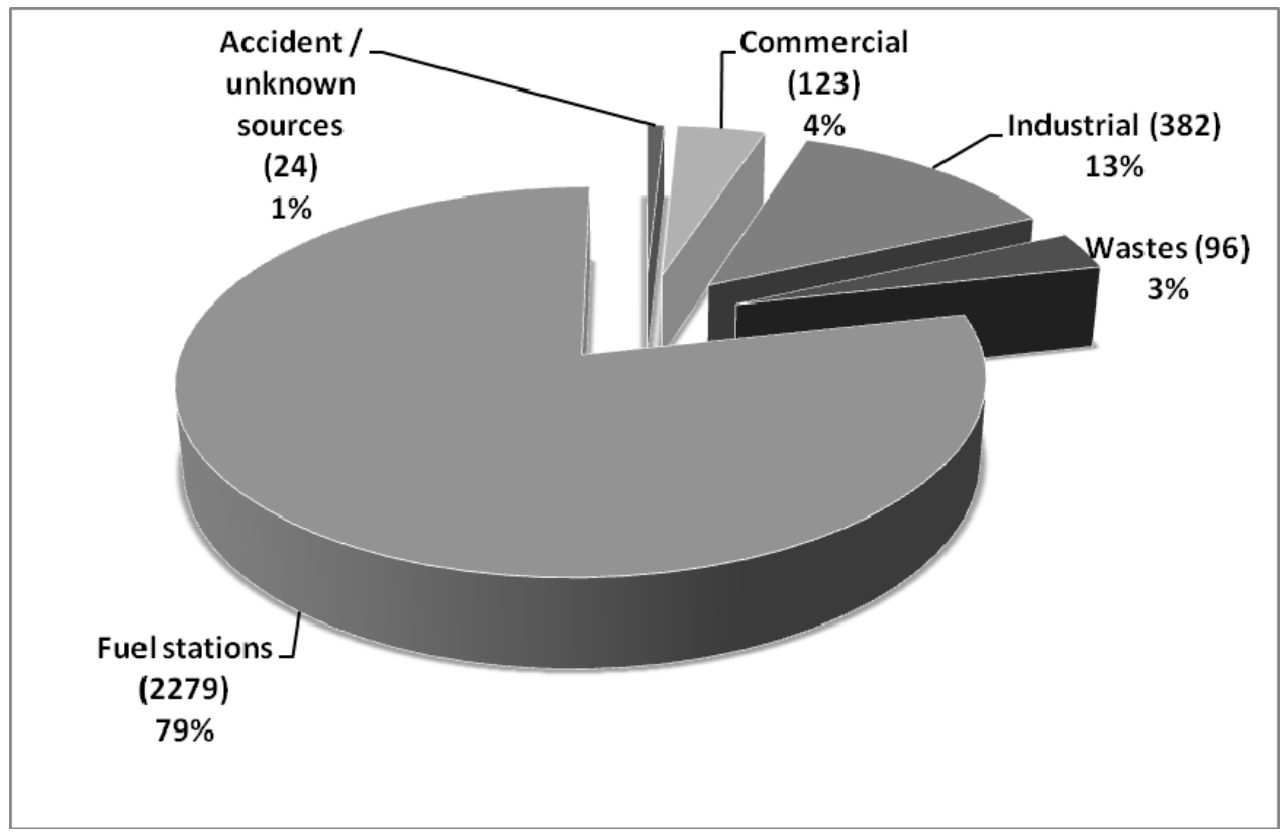

Figure 1. Distribution of contaminated areas according to activity - Nov/2009 [7].

Most commonly used remediation techniques in Brazil: The first contaminated sites in Brazil were identified during the 1980's. The first remediation actions occurred in 1991, when pump-and-treat technique was used to remediate aquifers contaminated with petroleum in underneath fuel stations. The next years were followed by a large number of environmental diagnosis and intensive technology development and transfer, particularly in Sao Paulo metropolitan area. In 1997 the technique soil vapour extraction (SVE) and air injection in saturated zone named air sparging (AS) were introduced in Brazil. The Industrial Area of Camaçari in Bahia State was the first area remediated with these technologies [8]. 


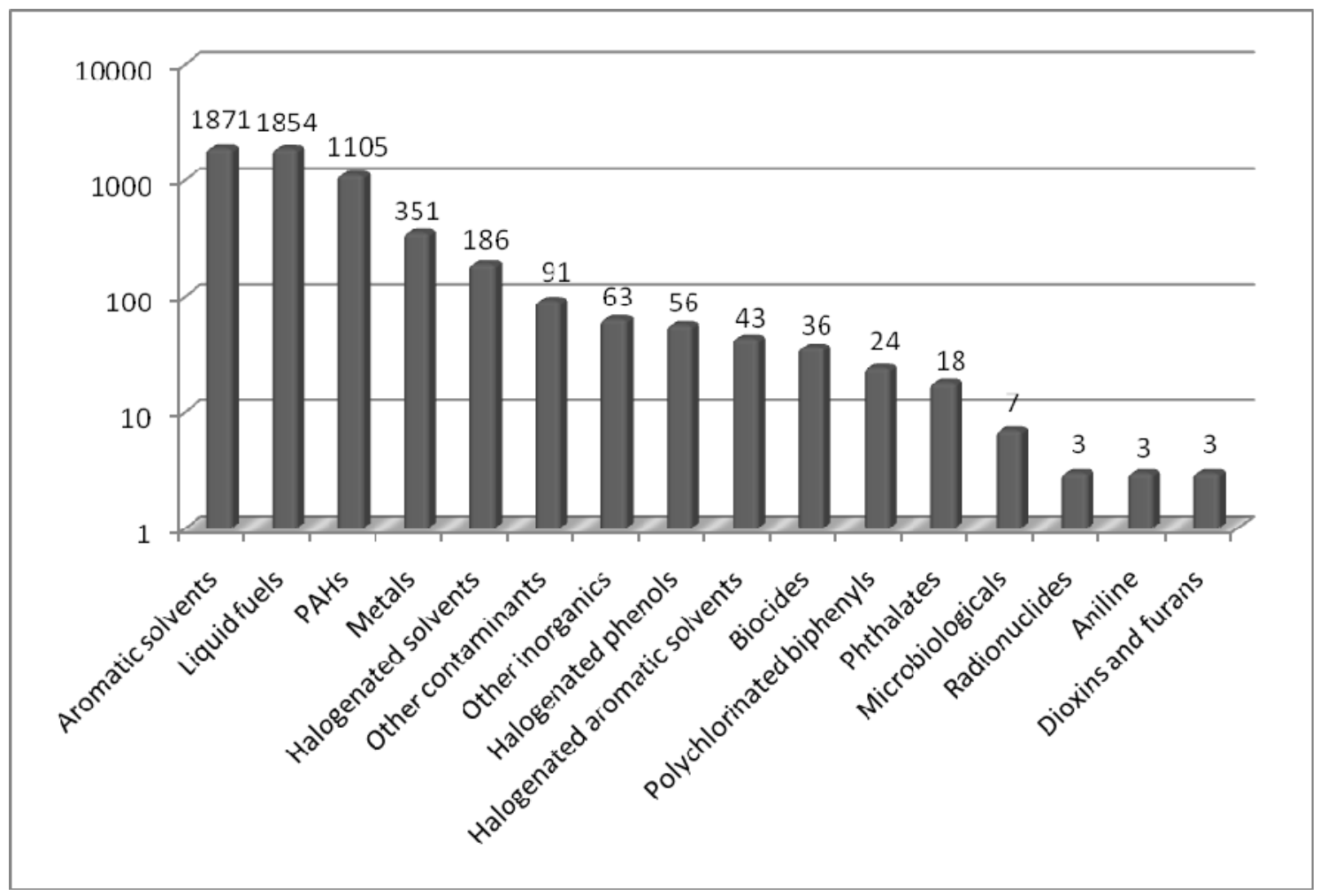

Figure 2: Registration of contaminants responsible for contaminated areas Nov/2009 [7].

Between 1999 and 2000 the first multiphase extraction (MPE) combining the benefits of pumping and soil vapour extraction were used, being this strategy the one applied to areas contaminated with hydrocarbons less dense than water, as it is the case of fuel stations, rail terminals for fuel distribution and the petrochemical industries. During the first years of the $21^{\text {st }}$ century, companies coming from Canada, USA, Germany and France brought new equipment and technologies to Brazil through cooperation with well-established local companies to implement remediation systems based on Advanced Oxidative Processes (AOPs), reactive barriers, and in situ bioremediation. According to [7], in 1.275 areas undergoing remediation or already remediated by 2009, pump and treat $(\mathrm{P} \& \mathrm{~T})$, recovery of free phase and multiphase extraction had been the techniques chosen in $68 \%$ of the cases (Figure 3), which reflected two aspects: (a) the large number of fuel stations undergoing remediation due to leaking from storage tanks; (b) reduced technological knowledge particularly found in small and medium size companies, which give service to the fuel distribution network, since these techniques are simple to apply and the investments required are relatively low, compared to more advanced techniques. In 2009, the next two most commonly used techniques were vapour extraction and soil and waste removal, which together represented $20 \%$ of the remediation projects. The other technological options brought from abroad still require further adaptation to the local conditions in order to produce efficiency and effective results. Figure 4 shows the evolution during the years of different remediation techniques in USA, which is currently one of the most advanced and mature markets in the world. During the 1980's the prevalence of pump and treat $(\mathrm{P} \& \mathrm{~T})$ was progressively replaced by monitored natural attenuation-MNA and bioremediation. As previously mentioned (Figure 3), in Brazil the stage is still the prevalence of P\&T, suggesting the juvenile nature of the remediation market. 


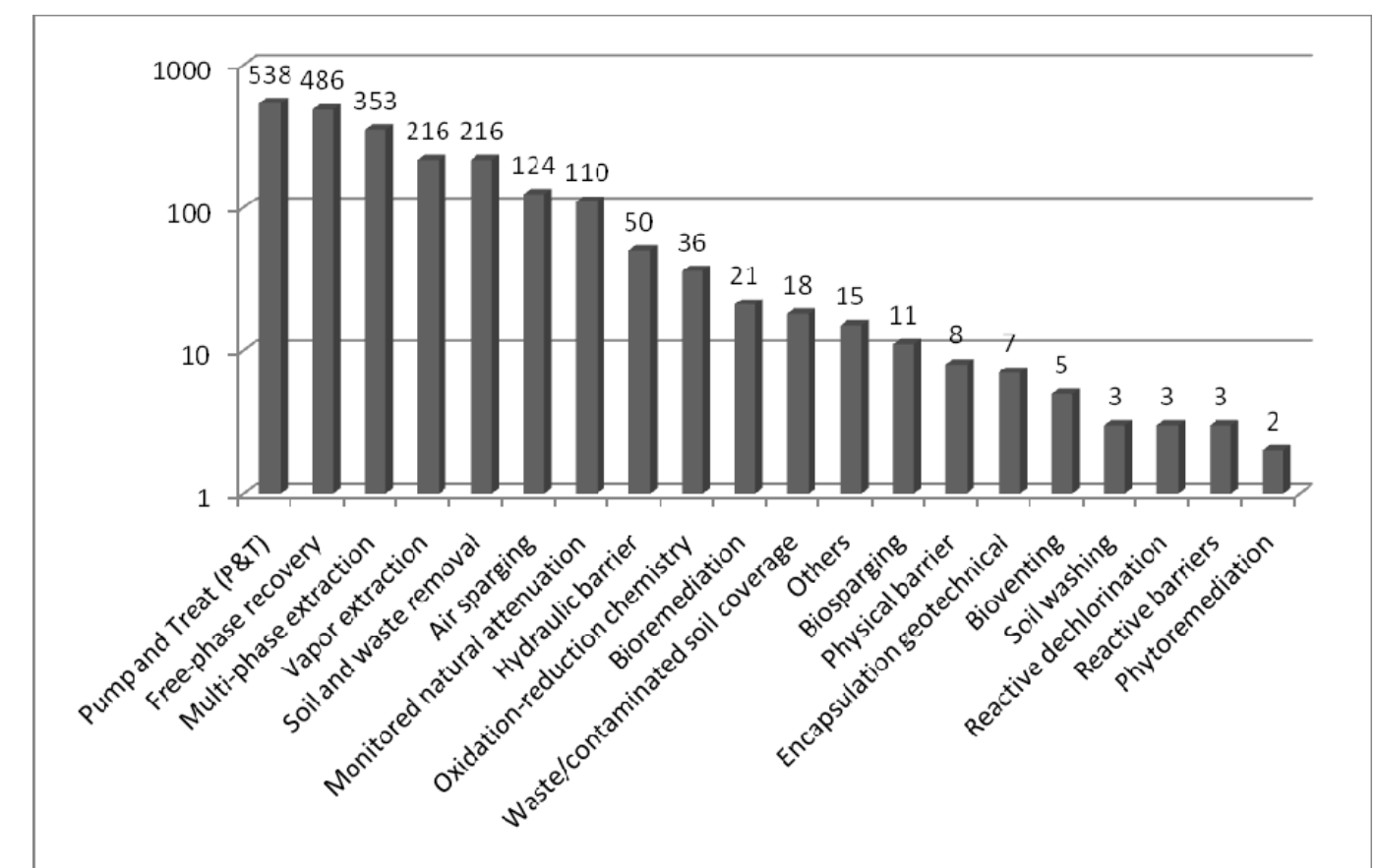

Figure 3. Frequency of use of different remediation techniques in Brazil by Nov 2009 [7].

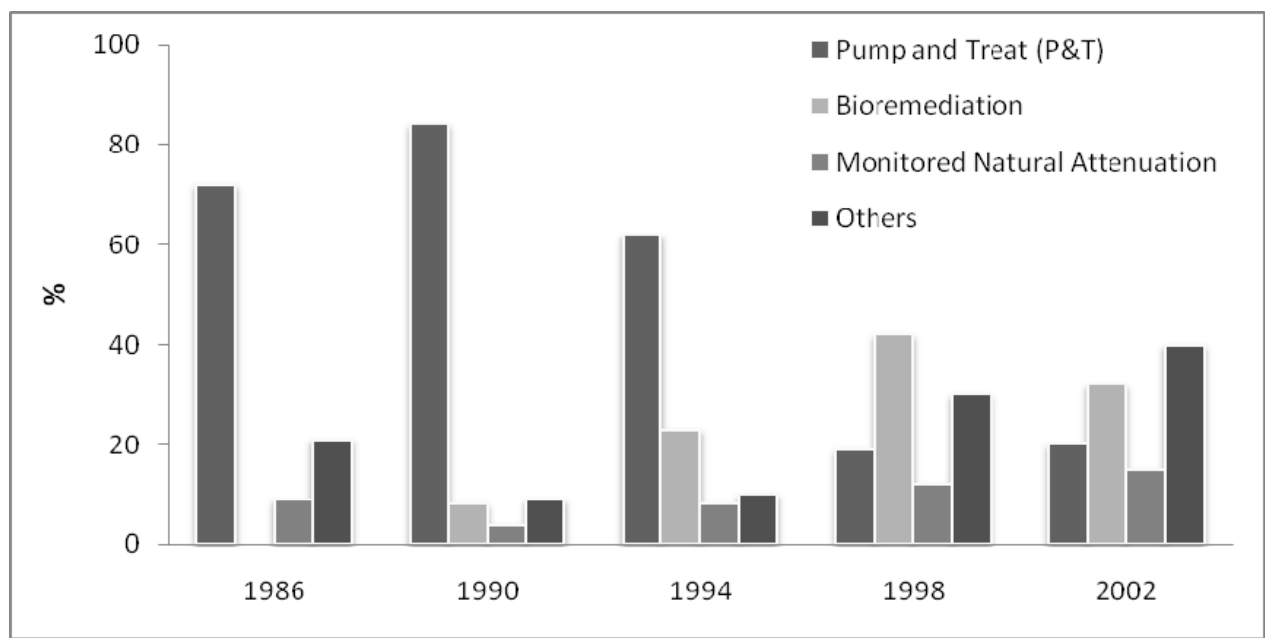

Figure 4. Evolution of remediation techniques in USA market [6].

In Brazil, among 200 companies that offered services for pollution control and abatement with focus on remediation of contaminated sites, 100 has the headquarter in Sao Paulo [9]. Among them, 2\% are large-size companies with annual income of US\$ 30 million, $7 \%$ are medium-size companies with annual income between 4.5 and 30 US\$ million. The remaining $91 \%$ are small-size companies with annual income below US\$ 4.5 million.

\section{BIOREMEDIATION OPTION}

Bioremediation can be regarded as an attractive technology that results in the partial or complete biotransformation of organic contaminants to microbial biomass and stable innocuous end-products such as $\mathrm{CO}_{2}$ and water. Moreover, this technology seems to be 
cost effective and environmentally accepted [10]. In situ bioremediation includes bioventing, biosparging, bioaugmentation and intrinsic bioremediation or natural attenuation. An ex situ bioremediation can be carried out through landfarming, static biopiles and bioreactors. The main advantages of in situ bioremediation are: (a) the fact that there is no need for removal of soil or groundwater; (b) the fact that an effective transformation of contaminants occurs, instead of contaminants removal or immobilization, which might not be a permanent solution. An ex situ bioremediation has the advantage of allowing major intervention and better control of variables, being also faster and less dependent o the hydraulic conductivity, as it is the case of in situ bioremediation. The last property is particularly important when remediating clayey soils. Its main disadvantage is the need for excavation/removal of soil or groundwater. Many environmental variables can affect the biodegradation process in different levels affecting the microorganism's growth and metabolism and/or the physical and chemical properties of the contaminants [11]. Such variables are:

- Microbial population: Microorganisms must be in sufficient number [12] and resist to the toxic effect of contaminants, which in turn depends on concentration. When the population of indigenous microorganisms capable of degrading the target contaminant is less than $10^{5}$ colony-forming units (CFU) per gram of soil, bioremediation will not occur at a significant rateToo low concentration of contaminants might also limit biodegradation [13]. Different factors in the soil might affect the microorganism's metabolism.

- Hydraulic conductivity (k): It must be sufficiently high to allow transportation of nutrients and electron's acceptor through the soil and/or aquifer and it is particularly relevant for in situ bioremediation. Soils with $\mathrm{k}>10^{-4} \mathrm{~cm} \mathrm{~s}^{-1}$ are considered the most suitable ones to be treated by in situ bioremediation [12].

- Temperature: According to Atlas et al. (1998), the enzymatic degradation and the microbial metabolism, double every $10{ }^{\circ} \mathrm{C}$ until a temperature around $40{ }^{\circ} \mathrm{C}$ is reached; from this point, temperature has the opposite effect (inhibition) to most microorganisms. In high temperatures, proteins might be damaged. Thermophile microorganisms can also bioremediate [14]. Under very low temperatures, the kinetics slows down due to increasing viscosity and reduced water solubility of contaminants, promoting the volatilization of toxic alcanes of low molecular weight.

- Moisture: The most suitable range depends on the field capacity and it is important for nutrients diffusion and microbial mobility [13]. The optimum moisture range goes from 25 to $85 \%$ of the field capacity.

- Electron acceptors: The petroleum hydrocarbons biodegradation occurs due to oxidation-reduction reactions, where the hydrocarbon is oxidized (electron donor) and a compound which play the role of electron acceptor is reduced. Compounds that act as electron acceptors include $\mathrm{O} 2$, nitrates, iron oxides, sulphates, water and $\mathrm{CO} 2$, being this the decreasing preferential order. Acceptors with higher oxidation potential result in faster oxidation of hydrocarbons [15]. Dissolved $\mathrm{O}_{2}$ is a limiting factor, since besides acting as final electron acceptor in the aerobic metabolism, $t$ also works as substrate in the initial stages of petroleum bioremediation processes due to catabolism of aliphatic, cyclic and aromatic hydrocarbons by microorganisms that only initiate reactions catalyzed by enzymes such as mono- and dioxygenases [16]. Under anoxic or anaerobic conditions other electron acceptors are activated.

- $\boldsymbol{p H}$ : Soil $\mathrm{pH}$ has a direct action on the microbial metabolism; for instance, under acidic $\mathrm{pH}$, metals availability in solution increases, which makes the environment 
toxic to most microorganisms. The optimum range is around neutrality between 6 and 8 .

- Nutrients: Contaminated soil is normally deficient in nutrients, which are necessary to support the microorganisms' growth. Different C:N:P rates have been suggested, being the rate 100:10:1, the most frequently mentioned [17]. However, other rates have been considered appropriate studies with Brazilian soils, such as 100:1.25:1. Excessive nitrogen can inhibit some microorganisms, such as the lignin-degrading system of white-rot fungi (WRF) that has been described as a degrader of a wide range of organic pollutants, particularly in liquid phase.

- Contaminant bioavailability: Contaminants can adsorb to soil particles, rendering some contaminants unavailable to microorganisms for biodegradation. Thus, in some circumstances, bioavailability of contaminants depends not only on the nature of the contaminant but also on soil type. Hydrophobic contaminants, like petroleum hydrocarbons, have low solubility in water and tend to adsorb strongly in soil with high organic matter content

\subsection{Biopiles in Brazil: Transpetro}

Differently from windrows that require frequent turning (usually, once a week), biopiles which is also an ex-situ strategy require forced aeration and often use complementary suction of soil gas to feed air to the microbial community. It can be conducted on site but it requires careful waste management for optimization of the degradation rate. The contaminants removal efficiency achieved with biopiles depends first of all, on the type of contaminant and the type of soil and second, on how much is done to optimize the processes and how long the biopile is operated, being the level of optimization and treatment time directly related with the final cost per treated tonne of soil. Therefore, cost-benefit analysis as well as some level of risk assessment is usually necessary in order to define the level of remediation that is required. Table 2 presents a number of experiences with ex-situ bioremediation of sites contaminated with petroleum hydrocarbons in lab, pilot and full-scales. In Brazil, the Norm N-2622B created by Petrobrás (2006) with the objective of establishing the criteria for waste management and final disposal by the company suggests some treatment technologies, emphasizing that the choice must consider among other aspects, the smallest environmental impact, reduction of use of natural resources and evaluation of costs with transportation as well as the impact of the final costs. The BATNEEC concept (Best Available Techniques Not Exceeding Excessive Costs) must be applied when choosing the remediation technique. According to the survey carried out in August 2009 in the Corporative Waste System (Petrobrás-SCR), in a 36 month-period (from August 2006 to August 2009), Transpetro - the largest oil and gas transportation company of Brazil that works with transportation and storage activities of oil and byproducts, such as ethanol, bio-fuels and natural gas generated 258746 tonnes of soils contaminated with oil, meanwhile in the same period, 259233 tonnes of soil contaminated with oil, taken from contaminated areas were treated by the company. Data obtained from Petrobrás-SCR also showed that 225.898 tonnes $(87 \%)$ from the total were treated with biopile technology, giving a clear picture of the current importance of this technique in the country (Figure 5). Per tonne of treated soil, the average cost varied as following, according to the technology: biopile remediation (233.3 \pm 128.8 USD); Thermal desorption (316.7 \pm 52.9 USD); Cement coprocessing (758.6 \pm 309.3 USD) and; Incineration (1.400 USD). 
Table 2. Investigations about ex situ bioremediation of soils contaminated with petroleum hydrocarbons (BTEX, HTPs, HPAs).

\begin{tabular}{|c|c|c|c|c|c|c|c|}
\hline \multicolumn{2}{|r|}{$\begin{array}{l}\text { Scale: } \\
\text { 1. Lab-scale, microcosm; } 2 . \\
\text { Pilot scale; } 3 \text { Full-scale/ } \\
\text { Contaminant(s) in the soil }\end{array}$} & $\begin{array}{l}\text { Biological process applied } \\
\text { (aerobic or anaerobic) }\end{array}$ & $\begin{array}{l}\text { Microorganisms identified } \\
\text { (yes/no) } \\
\text { If yes, give the specie }\end{array}$ & $\begin{array}{l}\text { Soil origin or } \\
\text { soil type }\end{array}$ & $\begin{array}{l}\text { Region } \\
\text { (climate) }\end{array}$ & $\begin{array}{l}\text { Treatment } \\
\text { period } \\
\text { and } \\
\% \text { removal }\end{array}$ & Reference \\
\hline 1 & TPH & $\begin{array}{c}\text { Aerobic } \\
\text { (Oxygen reducing) }\end{array}$ & No identified & Tyrol, Austria & Tyrol, Austria & $\begin{array}{l}88 \text { days; } \\
88 \%\end{array}$ & 18 \\
\hline 1 & n-alkanes & $\begin{array}{c}\text { Aerobic } \\
\text { (Oxygen-reducing) }\end{array}$ & $\begin{array}{c}\text { Pseudomonas sp. BS2201, } \\
\text { BS2203 and Brevibacillus sp. } \\
\text { BS2202 }\end{array}$ & Moscow & $\begin{array}{l}\text { Temperate } \\
\text { Continental }\end{array}$ & $\begin{array}{l}\text { 10days; } \\
90-95 \%\end{array}$ & 19 \\
\hline 1 & n-alkanes & $\begin{array}{c}\text { Anaerobic } \\
\text { (Nitrate-reducing) }\end{array}$ & $\begin{array}{c}\text { Pseudomonas sp. BS2201, } \\
\text { BS2203 and Brevibacillus sp. } \\
\text { BS2202 }\end{array}$ & Moscow & $\begin{array}{l}\text { Temperate } \\
\text { Continental }\end{array}$ & $\begin{array}{l}50 \text { days; } \\
20-25 \%\end{array}$ & 19 \\
\hline 1 & PAHs & $\begin{array}{c}\text { Anaerobic } \\
\text { (Nitrate-reducing) }\end{array}$ & $\begin{array}{c}\text { Pseudomonas sp. BS2201, } \\
\text { BS2203 and Brevibacillus sp. } \\
\text { BS2202 }\end{array}$ & Moscow & $\begin{array}{l}\text { Temperate } \\
\text { Continental }\end{array}$ & $\begin{array}{l}50 \text { days; } \\
15-18 \%\end{array}$ & 19 \\
\hline 1 & $\begin{array}{c}\text { Benzene } \\
\text { microcosms }\end{array}$ & $\begin{array}{c}\text { Anaerobic } \\
\text { (Nitrogen-reducing) }\end{array}$ & Marinobacter & Okahoma & Temperate & $\begin{array}{c}12 \text { weeks; } \\
10 \%\end{array}$ & 20 \\
\hline 1 & $\begin{array}{c}\text { Benzene } \\
\text { microcosms }\end{array}$ & $\begin{array}{c}\text { Aerobic } \\
\text { (oxigen-reducing) }\end{array}$ & Marinobacter & Okahoma & Temperate & 4 weeks & 20 \\
\hline 1 & PAHs & $\begin{array}{c}\text { Aerobic } \\
\text { (oxigen-reducing) }\end{array}$ & $\begin{array}{c}\text { Acidovanax, Bordella, } \\
\text { Pseudomonas, Sphingomonas e } \\
\text { Variovorax }\end{array}$ & Canada & Low temperate & $\begin{array}{l}90 \text { days; } \\
52-88 \%\end{array}$ & 21 \\
\hline 1 & PAHs & $\begin{array}{c}\text { Anaerobic } \\
\text { (Nitrate-reducing }\end{array}$ & $\begin{array}{c}\text { Acidovanax, Bordella, } \\
\text { Pseudomonas, Sphingomonas e } \\
\text { Variovorax }\end{array}$ & Canada & Low temperate & $\begin{array}{l}90 \text { days; } \\
39 \%\end{array}$ & 21 \\
\hline 1 & PAHs & $\begin{array}{c}\text { Aerobic } \\
\text { (Oxygen reducing) }\end{array}$ & No identified & silt-clay type & Temparate & $75 \%$ & 22 \\
\hline 1 & $\mathrm{TPH}$ & $\begin{array}{c}\text { Aerobic } \\
\text { (Oxygen reducing) }\end{array}$ & No identified & $\begin{array}{l}\text { Brazil (Clay } \\
\text { soil)) }\end{array}$ & Tropical & $\begin{array}{l}24 \text { weeks; } \\
86.2 \%\end{array}$ & 13 \\
\hline
\end{tabular}


Linnaeus ECO-TECH '10

Kalmar, Sweden, November 22-24, 2010

\begin{tabular}{|c|c|c|c|c|c|c|c|}
\hline 1 & $\mathrm{TPH}$ & $\begin{array}{c}\text { Aerobic } \\
\text { (Oxygen reducing) }\end{array}$ & No identified & $\begin{array}{l}\text { Brazil (clay } \\
\text { soil) }\end{array}$ & Tropical & $\begin{array}{l}12 \text { weeks; } \\
70 \%\end{array}$ & 13 \\
\hline 1 & TPH & $\begin{array}{c}\text { Aerobic } \\
\text { (Oxygen reducing) }\end{array}$ & No identified & $\begin{array}{c}\text { Calcareous } \\
\text { sandy soil } \\
\text { Burgan, Kuwait } \\
\text { desert } \\
\end{array}$ & Desert & $\begin{array}{l}43 \text { weeks; } \\
15-33 \%\end{array}$ & 23 \\
\hline 1 & $\begin{array}{l}\text { TPH as diesel } \\
(\mathrm{C} 14-\mathrm{C} 20)\end{array}$ & $\begin{array}{c}\text { Aerobic } \\
\text { (Oxygen reducing) }\end{array}$ & No identified & $\begin{array}{l}\text { ( sub solo } \\
\text { aloino) }\end{array}$ & & $\begin{array}{l}155 \text { days; } \\
\quad 65 \%\end{array}$ & 18 \\
\hline 1 & $\begin{array}{c}\text { TPH as aviation kerosene } \\
\text { (C11-C14) }\end{array}$ & $\begin{array}{c}\text { Aerobic } \\
\text { (Oxygen reducing) }\end{array}$ & $\begin{array}{l}\text { Pseudomonas aeruginosa } \\
\text { Inoculum from four } \\
\text { contaminated sites }\end{array}$ & Brazil & Tropical & $\begin{array}{l}\text { Period? } \\
67-75 \%\end{array}$ & 16 \\
\hline 2 & $\begin{array}{l}\text { TPH as diesel } \\
(\mathrm{C} 14-\mathrm{C} 20)\end{array}$ & $\begin{array}{c}\text { Aerobic (oxygen-reducing) } \\
\text { switching } \\
\text { Anaerobic (xx-reducing) }\end{array}$ & No identified & Germany & Temperate & $\begin{array}{l}27 \text { day; } \\
50 \%\end{array}$ & 24 \\
\hline 2 & $\begin{array}{c}\text { PAHs (naphthalene, } \\
\text { phenantherene, metihyl- } \\
\text { naphthalene, fluorine e } \\
\text { fluoranthene) }\end{array}$ & Anaerobic (sulfat reducing) & No identified & San Diego Bay & Mediterranean & $\begin{array}{l}20 \text { days } \\
60-120 \%\end{array}$ & 25 \\
\hline 2 & $\mathrm{TPH}$ & $\begin{array}{c}\text { Aerobic } \\
\text { (Oxygen reducing) }\end{array}$ & No identified & Paulinea - SP & Tropical & $\begin{array}{l}14 \text { days; } \\
55-89 \%\end{array}$ & 26 \\
\hline 2 & PAH & $\begin{array}{c}\text { Aerobic } \\
\text { (Oxygen reducing) }\end{array}$ & No identified & Paulínea - SP & Tropical & $\begin{array}{l}14 \text { dias; } \\
70-88 \%\end{array}$ & 26 \\
\hline 2 & $\mathrm{TPH}$ & $\begin{array}{c}\text { Aerobic } \\
\text { (Oxygen reducing) }\end{array}$ & No identified & Germany & Temperate & $85 \%$ & 27 \\
\hline 2 & $\begin{array}{c}\text { TPH, n-alkanes, PAH } \\
\text { (dibenzo-thiophenes and } \\
\text { phenan-threnes) }\end{array}$ & $\begin{array}{c}\text { Aerobic } \\
\text { (Oxygen reducing) }\end{array}$ & No identified & - & - & $\begin{array}{l}11 \text { dias; } \\
50-62 \%\end{array}$ & 28 \\
\hline 2 & ТPH & $\begin{array}{c}\text { Aerobic } \\
\text { (Oxygen reducing) }\end{array}$ & No identified & $\begin{array}{c}\text { Clay soil, } \\
\text { Duque de } \\
\text { Caixias - RJ }\end{array}$ & Tropical & 120 dias; $81 \%$ & 29 \\
\hline
\end{tabular}


Linnaeus ECO-TECH ' 10

Kalmar, Sweden, November 22-24, 2010

\begin{tabular}{|c|c|c|c|c|c|c|c|}
\hline 3 & $\begin{array}{l}\text { Oily sludge from flare } \\
\text { bunker }\end{array}$ & $\begin{array}{c}\text { Aerobic } \\
\text { (Oxygen reducing) }\end{array}$ & No identified & $\begin{array}{l}\text { Alberta, } \\
\text { Canada }\end{array}$ & Temperate & $\begin{array}{l}8 \text { weeks; } \\
62-86 \%\end{array}$ & 30 \\
\hline 3 & $\begin{array}{l}\text { TPH as diesel } \\
\text { (C14-C20) }\end{array}$ & $\begin{array}{c}\text { Aerobic } \\
\text { (Oxygen reducing) }\end{array}$ & No identified & $\begin{array}{l}\text { Nebraska, } \\
\text { USA }\end{array}$ & Temperate & $\begin{array}{l}52 \text { weeks; } \\
38,9 \%\end{array}$ & 31 \\
\hline 3 & $\begin{array}{l}\text { TPH as diesel }(\mathrm{C} 14-\mathrm{C} 20) \\
\text { and aviation kerosene } \\
(\mathrm{C} 11-\mathrm{C} 14)\end{array}$ & $\begin{array}{c}\text { Aerobic } \\
\text { (Oxygen reducing) }\end{array}$ & No identified & $\begin{array}{l}\text { Marine Corps, } \\
\text { Havaí, USA }\end{array}$ & Temperate & $\begin{array}{l}7 \text { weeks, } \\
57,1 \%\end{array}$ & 32 \\
\hline 3 & Intemperic hydrocarbons & $\begin{array}{c}\text { Aerobic } \\
\text { (Oxygen reducing) }\end{array}$ & No identified & USA & Temperate & $\begin{array}{l}45 \text { weeks, } \\
55 \%\end{array}$ & 33 \\
\hline 3 & $\begin{array}{l}\text { TPH as lubricating oil } \\
\text { (C20-C40) }\end{array}$ & $\begin{array}{c}\text { Aerobic } \\
\text { (Oxygen reducing) }\end{array}$ & No identified & Serdp, USA & Temperate & $\begin{array}{l}47 \text { weeks, } \\
70,4 \%\end{array}$ & 34 \\
\hline 3 & TPH as Diesel (C14-C20) & $\begin{array}{c}\text { Aerobic } \\
\text { (Oxygen reducing) }\end{array}$ & No identified & Serdp, USA & Temperate & $\begin{array}{c}47 \text { weeks, } \\
87,6 \%\end{array}$ & 34 \\
\hline 3 & $\begin{array}{l}\text { TPH as lubricating oil } \\
\text { (C20-C40) and TVOC }\end{array}$ & $\begin{array}{c}\text { Aerobic } \\
\text { (Oxygen reducing) }\end{array}$ & No identified & $\begin{array}{l}\text { Helsinki, } \\
\text { Finland }\end{array}$ & Temperate & $\begin{array}{l}21 \text { weeks, } \\
70 \%\end{array}$ & 35 \\
\hline 1 & $\begin{array}{c}\mathrm{TPH} \\
\text { (microcosm) }\end{array}$ & Aerobic & No identified & $\begin{array}{l}\text { Clay loam, } \\
\text { China }\end{array}$ & $\begin{array}{l}\text { Temperate, } \\
\text { continental-type } \\
\text { monsoon } \\
\text { climate }\end{array}$ & 12 weeks, $61 \%$ & 36 \\
\hline 1 & $\begin{array}{c}\text { PAH (fluorene, } \\
\text { phenanthrene, anthracene, } \\
\text { flouranthene, pyrene and } \\
\text { benzoanthracene) } \\
\text { (Lab-scale reactor) }\end{array}$ & Aerobic & No identified & $\begin{array}{l}\text { Sandy loam, } \\
\text { Spain }\end{array}$ & Mediterranean & $\begin{array}{l}30 \text { days, } \\
96.53 \%\end{array}$ & 37 \\
\hline 3 & $\begin{array}{c}\text { TPH, } \\
\text { (windrow) }\end{array}$ & Aerobic & No identified & Scotland & Temperate & 28 weeks, $98 \%$ & 38 \\
\hline 3 & $\begin{array}{c}\mathrm{TPH}, \\
\text { (Biopiles) }\end{array}$ & Aerobic & No identified & Scotland & Temperate & 28 weeks, $78 \%$ & 38 \\
\hline 1 & $\begin{array}{c}\text { TPH, n-alkanes } \\
\text { (Lab-scale reactor) }\end{array}$ & Aerobic & $\begin{array}{c}\text { Glomus caledonium NW03 and } \\
\text { Bacillus subtilis NW08 }\end{array}$ & China & Temperate & $\begin{array}{l}60 \text { days, } \\
92.6 \%\end{array}$ & 39 \\
\hline 1 & $\begin{array}{c}\text { TPH } \\
\text { (bench-scale bioreactor) }\end{array}$ & Aerobic & No identified & $\begin{array}{l}\text { Coarse } \\
\text { grained, } \\
\text { Canada }\end{array}$ & Polar desert & 313 days, $66 \%$ & 40 \\
\hline
\end{tabular}


Linnaeus ECO-TECH ' 10

Kalmar, Sweden, November 22-24, 2010

\begin{tabular}{|c|c|c|c|c|c|c|c|}
\hline 3 & $\begin{array}{c}\text { TPH } \\
\text { (landfarming experiment) }\end{array}$ & Aerobic & No identified & $\begin{array}{c}\text { Coarse } \\
\text { grained, } \\
\text { Canada } \\
\end{array}$ & Polar desert & 3 years, $50 \%$ & 40 \\
\hline 1 & $\begin{array}{c}\text { TPH } \\
\text { (bench-scale bioreactor) }\end{array}$ & Aerobic & No identified & $\begin{array}{l}\text { Sandy loam } \\
\text { soil, Brazil }\end{array}$ & Tropical & $\begin{array}{c}42 \text { days, } \\
19.6 \%\end{array}$ & 41 \\
\hline 2 & $\begin{array}{c}\text { TPH } \\
\text { (pilot-scale bioreactor) }\end{array}$ & Aerobic & No identified & $\begin{array}{l}\text { Sandy loam } \\
\text { soil, Brazil }\end{array}$ & Tropical & $\begin{array}{l}42 \text { days, } \\
35.1 \%\end{array}$ & 41 \\
\hline 3 & $\begin{array}{c}\mathrm{TPH} \\
\text { (pilot-scale bioreactor) }\end{array}$ & Aerobic & No identified & Milan, Italy & Temperate & 9 weeks, $60 \%$ & 42 \\
\hline 1 & $\begin{array}{l}\text { Hydrocarbons (n- } \\
\text { hexadecane, n-octane; n- } \\
\text { dodecane, xylene) }\end{array}$ & Aerobic & $\begin{array}{l}\text { Pseudomonas aerugenona and } \\
\text { Rhodococcus sp. }\end{array}$ & $\begin{array}{l}\text { Faridabad and } \\
\text { Ratnagiri, } \\
\text { India } \\
\end{array}$ & - & 6 weeks, $90 \%$ & 43 \\
\hline 1 & $\begin{array}{c}\text { Fuel oil (aliphatic and } \\
\text { aromatic hydrocarbons) } \\
\text { (lab-scale reactor) }\end{array}$ & Aerobic & No identified & $\begin{array}{c}\text { Aridisol } \\
\text { Atacama } \\
\text { Region, Chile }\end{array}$ & Desert & 56 days, $59 \%$ & 44 \\
\hline
\end{tabular}




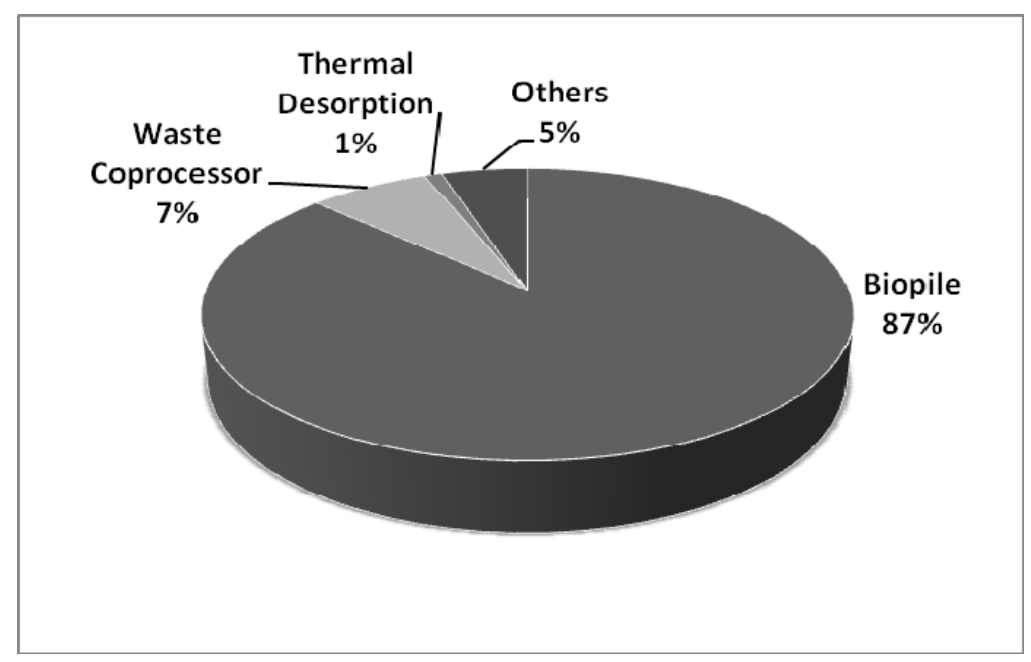

Figure 5. Remediation technologies used from August 2006 to August 2009 to treat 258746 tons of soil contaminated with petroleum hydrocarbons (Petrobrás SCR, 2009).

\section{FINAL REMARKS}

Bioremediation is clearly increasing in the world and particularly in Brazil, as a cost-effective alternative to treat soil contaminated with petroleum and its products. However, more investigation and process control, followed by equipment and technique development is required. On the other hand, the end-point of remediation needs to be better defined relative to the receptor that requires protection. Often, soil that shows significant recovery regarding removal of target contaminants might be still impaired with respect to human and/or ecological risk.

\section{ACKNOWLEDGEMENTS}

The financial supports from CNPq, FAPERJ and the company Lumina Resíduos Industriais (Foz do Iguaçu/Odebretcht Group) to the research group are acknowledged.

\section{REFERENCES}

[1] Ayres da Silva, A.C.M. 2002. A importância dos fatores ambientais na reutilização de imóveis industriais em São Paulo (in Portuguese). MSc thesis. EP/USP, SP, 107 p.

[2] Public Waste Agency of Flanders. Soil remediation. Available in http://www.ovam.be/ accessed in May 2008.

[3] European Groundwater and Contaminated Land Remediation Information System (EUGRIS).Portal for soils and water management in Europe. 2000 Disponível em: http://www.eugris.info/ Germany. Accessed in May, 2008.

[4] République Française. Ministére de L'Ecologie et du Devenoppement Durable. Pollution des sols. Basol. 2008. Available in http://basol.environnement.gouv.fr/ tableaux/home.htm Accessed in May, 2008.

[5] Swedish Environmental Objectives Council. 2005. Sweden's Environmental Objectives, 2005. $81 \mathrm{p}$. 
[6] USEPA. United States Environmental Protection Agency. Available at: http:/www.epa.gov. Accessed in May 2008.

[7] CETESB. Available at: http:/www.cetesb.sp.gov.br. Accessed in 2010.

[8] Alarsa, M., Viana Jr., O., Spilbhorgs, M.C.F. 1998 Evaluation of In Situ Remediation Technologies in a Petrochemical Area - A Field Study at COPENE Site. Proceeding of the International Symposium on Management Operation of Environmental Control Systems in the Chemical and Petrochemical Industry, Salvador - BA.

[9] AESAS. Associação Brasileira das Empresas de Consultoria e Engenharia Ambiental. Palestra Panorama mercadológico - normalizações, Maurício Prado Alves. V Seminário de Políticas de Gestão de Qualidade do Solo e das Águas Subterrâneas, São Paulo, 19 e 20 de Setembro de 2007

[10] Haritash, A.K., Kaushik, C.P. 2009. Biodegradation aspects of polycyclic aromatic hydrocarbons (PAHs): a review, J. Hazard. Mater. 169:1-15.

[11] Providenti, M. A., Lee, H. e Trevors, J. T. 1993. Selected Factors Limiting the Microbial Degradation of Recalcitrant Compounds. Journal of Industrial Microbiology, 12:379-395

[12] Wise, D.L., Trantolo, D.J., Cichon, E.J., Inyang, H. I., Stottmeister, U. Remediation Engineering of Contaminated Soils, CRC Press, 996p, 2000.

[13] Seabra, P.N.C, Landa, F.G, Frota, G.B., Platte, E.B., Casella, R.C. 2005. Bioremediation of Petroleum Hydrocarbons in High Clay Content Soils. $8^{\text {th }}$ International In Situ On-Site Bioremediation Symposium, Baltimore, EUA, 6-9 June.

[14] Kriipsallu, M., Marques, M., Nammari, D.R., Hogland, W. 2007. Bio-treatment of oily sludge: The contribution of amendment material to the content of target contaminants and the biodegradation dynamics. Journal of Hazardous Materials, 148:616-622.

[15] Corseuil, H. X.; Alvarez, P. J. J. Natural bioremediation perspective for BTEX contaminated groundwater in Brazil: effect of ethanol. Wat. Sci. Tech., v. 34, p.311-318,1996.

[16] Cravo Júmior, W. B. Biodegradação de querosene de aviação (QAV) por culturas mistas e por Pseudomonas aeruginosa. 1998. 68p. MSc Thesis - Escola de Química, Universidade Federal do Rio de Janeiro, Rio de Janeiro.

[17] Riser-Roberts, E. Remediation of petroleum contaminated soils: biological, physical, and chemical processes. Lewis Publishers, 1998.

[18] Margesin, R., Zinmerbauer, A. and Schinner F. Monitoring of bioremediation by soil biological activities. Chemosphere, v. 40, p. 339-346, 2000.

[19] Grishchenkov, V. G.; Townsend, R. T.; McDonald, T.J.; Autenrieth, R.L.; Bonner, J.S.; Boronin, A.M. 2000. Degradation of petroleum hydrocarbons by facultative anaerobic bacteria under aerobic and anaerobic conditions - Process Biochemistry, 35:889-896.

[20] Nicholson, C. And Fathepure, B. 2003. Biodegradation of benzene under aerobic and anaerobic conditions by halophilic bacteria. Poster Q-035 at American Society of Microbiology $103^{\text {rd }}$ General Meeting, Washington, D.C. May 18-22.

[21] Eriksson, M., Sodersten, E. ; Yu, Z.; Dalhammar, G. and Mohn, W. W. 2003. Degradation of Polycyclic Aromatic Hydrocarbons at Low Temperature under Aerobic and Nitrate-Reducing Conditions in Enrichment Cultures from Northern Soils. American Society for Microbiology.

[22] Nocentini, M.; Pinelli, D. 2001. Bioremediation of PAHs in Aggregates of a Low Permeability. Soil and Sediment Contamination, v. 10, n.2, p. 211-226. 
[23] Cho, B.H., Chino, H., Tsuj, H., Kunito, T., Nagaoka, K., Otsuka, S., Yamashita, K., Matsumoto, S., Oyaizu, H. 1997. Laboratory-scale bioremediation of oil-contaminated soil of Kuwait with soil amendment materials. Chemosphere, Volume 35, Issue 7, Pages 1599-1611.

[24] Löser, C., Seidel, H., Zehnsdorf, F. A. and Stottmeister, U. 1998. Microbial degradation of hydrocarbons in soil during aerobic/anaerobic changes and under purely aerobic conditions. Applied Microbiology and Biotechnology v.49(5), p.631-636.

[25] Coates, J., Woodward, J., Jon Allen, J., Philip, P. and Lovley, D. 1997. Anaerobic Degradation of Polycyclic Aromatic Hydrocarbons and Alkanes in Petroleum-Contaminated Marine Harbor Sediments. Applied and Environmental Microbiology. 63:3589-3593.

[26] Berger, T.M. 2005. Biorremediação de solos contaminados com hidrocarbonetos totais do petróleo - enfoque na aplicação do processo terraferm. Tese de Doutorado. Departamento.de Ecologia. Universidade Federal do Rio Grande do Sul. Porto Alegre.

[27] Henke, G. 1994. Grundlagen der mikrobiologischen Sanierrung - mit Fallbeispielen. In: KIEFER, K-M. Altlastensanierrung: Sicherung, Sanierung und Folgenutzung kontaminierter Flächen. Berlin: Springer, pp. 107-116.

[28] Brown L.J., Syslo, J, Lin, Y., Getty, S., Vemuri, R., Nadeau, R. 1998. On-site treatment of contaminated soils: an approach to bioremediation of weathered petroleum compounds. Journal of Soil Contamination, 7(6):773-800.

[29] Vaz, M.J. 2010. Biodegradação ex-situ e avaliação da atividade biológica de solos contaminados por hidrocarbonetos. Universidade de Santa Cruz do Sul, Rio Grande do Sul. MSc Thesis. Departamento de Tecnologia Ambiental. Universidade Santa Cruz do Sul UNICS, Santa Cruz do Sul.

[30] McMillen, S.J., Kerr, J.M., Brunet, J.M., Moir, M.E., Nicholson, P., Qualizza, C.V., Moreau, R., Herauf, D.. 1996. .Composting in Cold Climates: Results from two Field Trials. In: SPE International Conference on Health, Safety, and Environmental, New Orleans, USA, June 912, pp. 19-30.

[31] Cyr, G.G., Spieles, P.R., 1997. Enhanced Biopile Aeration Using a Wind-Powered Ventilation System: Case Study. In: In Situ and On-site Bioremediation: Vol 1. Pat. Int. In Situ On-Site Bioremediation. Symp., New Orleans, USA, April 28- May 1 1997, $4^{\text {th }}$, pp. 473-78. Alleman, B.C., Leeson, A. (eds), Battelle Press, Columbus, Ohio.

[32] Von Fahnestock, F.M., Wickramanayake, G.B., Kratzke, R.J., Major, W.R. 1998. Biopile Design, Operation and Maintenance Handbook for Treating Hydrocarbon-Contaminated Soils. Columbus, Battelle Press.

[33] Hayes, K.W., Meyers, J.D., Huddleston, R.L. 1995. Biopile treatability, bioavailability, and toxicity evaluation of a hydrocarbon-impacted soil. In: Applied Bioremediation of Petroleum Hydrocarbons: Pat. In Situ On-Site Bioremediation. Int. Symp., San Diego, USA, April 24-27 1 1995, pp. 249-256. Hinchee, R.E., Miller, R.N., Johnson, P.C. (eds), Battelle Press, Columbus, Ohio.

[34] Chaconas, J.D.J, Van Deinse, H., Medearis, S., Grasmick, D., Major, W.R., Chaudhry, T. 1997. Bioremediation of Diesel-Contaminated Soils at Navy National Test Site. In: In Situ and On-site Bioremediation: Volume 1, Pat. Int. In Situ On-Site Bioremediation. Symp., New Orleans, USA, April 28- May 1 1997, 4 ${ }^{\text {th }}$, pp. 497-502. Alleman, B.C., Leeson, A. (eds), Battelle Press, Columbus, Ohio.

[35] Jørgensen, K.S., Puustinen, J., Suortti, A.M. 2000. Bioremediation of Petroleum Hydrocarbon-Contaminated Soil by Composting in Biopiles. Environmental Pollution, 107:245-254. 
[36] Yaohui, X. and Mang Lu. 2010. Bioremediation of crude oil-contaminated soil: Comparison of different biostimulation and bioaugmentation treatments. Journal of Hazardous Materials, 183(1-3):395-401.

[37] Sayara, T., Sarra, M., Sanchez, A. 2010. Effects of compost stability and contaminant concentration on the bioremediation of PAHs-contaminated soil through composting. Journal of Hazards Materials. 179(1-3): 999-1006.

[38] Coulon, F., Awadi, M. Al. Cowie, W., Mardllin, D., Pollard, S., Cunningham, C., Risdon, G., Arthur, P., Semple, K.T., Paton, G.I. When is a soil remediated? Comparison of biopiled and windrowed soils contaminated with bunker-fuel in a full-scale trial. Environmental Pollution 158:3032-3040.

[39] Chen, L.; Chen, Y.; Chen, L.; Chen, W. 2009. Study on fungi-bacteria augmented remediation of petroleum contaminated soil from Northwest of China. International journal of food, agriculture and environment. 7(3-4):750-753.

[40] Sanscartier, D., Laing, T., Reimer, K., Zeeb, B. 2009. Bioremediation of weathered petroleum hydrocarbon soil contamination in the Canadian High Arctic: Laboratory and field studies. Chemosphere. 77(8): 1121-1126.

[41] Rizzo, A.C.L.; Santos, R.M.; Santos, R.L.C.; Soriano, A.U.; Cunha, C.D.; Rosado, A.S.; Sobral, L.G.S.; Leite, S.G.F..2010. Petroleum-contaminated soil remediation in a new solid phase bioreactor. Journal of Chemical Technology \& Biotechnology. 85(9):1260-1267.

[42] Naano, G., Borroni, A., Rota, R. 2003. Combined slurry and solid-phase bioremediation of diesel contaminated soils. Journal of Hazardous Materials. 100( 1-3): 79-94.

[43] [43] Cameotra, S.S.; Singh, P. 2008. Bioremediation of oil sludge using crude biosurfactants. International Biodeterioration \& Biodegradation 62(3):274-280.

[44] Godoy-Faundez, A., Antizar-Ladislao, B., Reyzes-Bozo, L.; Camaño, A. and Saez-Navarrete, C. 2008. Bioremediation of contaminated mixtures of desert mining soil and sawdust with fuel oil by aerated in-vessel composting in the Atacama Region (Chile). Journal of Hazardous Materials. 151(2-3): 649-657. 